\title{
Article \\ Combining Total Cost of Ownership and Multi-Criteria Decision Analysis to Improve Cost Management in Family Farming
}

\author{
Mauro Lizot ${ }^{1, *(D)}$, Flavio Trojan ${ }^{1}(\mathbb{D})$ and Paulo Afonso ${ }^{2}(\mathbb{D}$ \\ 1 Department of Production Engineering, Federal University of Technology Parana (UTFPR), Avenue Doutor \\ Washington Subtil Chueire, 330, Jardim Carvalho, Ponta Grossa 84017-220, Brazil; trojan@utfpr.edu.br \\ 2 Department of Production and Systems, Algoritmi Research Centre, University of Minho, Campus Azurém, \\ 4804-533 Guimarães, Portugal; psafonso@dps.uminho.pt \\ * Correspondence: mauro.lizot@unochapeco.edu.br; Tel.: +55-49-99911-2774
}

Citation: Lizot, M.; Trojan, F.; Afonso, P. Combining Total Cost of Ownership and Multi-Criteria Decision Analysis to Improve Cost Management in Family Farming. Agriculture 2021, 11, 139. https:// doi.org/10.3390/agriculture11020139

Academic Editor: Sanzidur Rahman Received: 16 December 2020

Accepted: 3 February 2021

Published: 8 February 202

Publisher's Note: MDPI stays neutra with regard to jurisdictional claims in published maps and institutional affiliations.

Copyright: (c) 2021 by the authors. Licensee MDPI, Basel, Switzerland. This article is an open access article distributed under the terms and conditions of the Creative Commons Attribution (CC BY) license (https:// creativecommons.org/licenses/by/ $4.0 /)$
Abstract: Family farming is an important pillar of the global primary food sector and is characterized by a significant local and regional impact. The sustainability of these businesses depends greatly on the use of effective management practices in family farming and smallholder farmer's activities. However, there is a lack of methodologies to support decision making in this sector related to the recognition of all aspects involved in the acquisition of inputs. Commonly, the existing approaches are focused on cost as the major criterion, which might impact on the agribusiness sustainability in the short or long term. Furthermore, traditional cost-focused approaches should be complemented with multi-criteria aspects within comprehensive and practical methodologies. This paper presents a Cost Management Model (CMM) integrating the concepts of Total Cost of Ownership (TCO) and Multiple Criteria Decision Analysis (MCDA), which includes both monetary and non-monetary attributes. The use of TCO was mostly focused on industrial applications and studies on costs in agribusiness are still scarce and incomplete. The model was applied to a set of agribusiness families in Southern Brazil to support the supplier selection process of the three main inputs (i.e., fertilizer, fungicide, and soybeans). A significant cost reduction of approximately $13 \%$ for fertilizers, $7 \%$ for fungicides, and $3 \%$ for soybeans can be achieved. The CMM can be applied by smallholder farmers in any region of the world, and its flexibility allows changes in weights and criteria at any time by the decision maker. Buyers are more prepared to select the best supplier for each input and the later can recognize how they are more or less competitive when all costs and relevant criteria are taken into consideration. It can be also applied from an industry-level perspective to highlight the industry's cost structure and value chain, supporting more focused and effective public policies namely the design of subsidies that mitigate relevant context costs and the investment in infrastructures. Both, subsidies and public investment, are of major importance in rural areas of developing countries.

Keywords: total cost of ownership; multi-criteria analysis; family farming

\section{Introduction}

Small farmers have a significant share of the global primary food sector and a significant local and regional impact. Management practices, in general, and cost management, in particular, need to be improved significantly in small agribusiness companies. Nevertheless, to be effective, these practices need to balance adequately comprehensiveness, theoretical and technical robustness and practical effectiveness, recognizing the needs and limitations of these companies. A proper management of costs is an important issue in the agenda for the improvement of the agriculture economy, in general, and specifically, in the context of family farming. The increasing global demand pressure and consumer awareness combined with more rigorous legislation pushes simultaneously price reductions and higher quality.

A true effective and efficient costs reducing program in agribusiness starts and should be mainly leveraged with actions to support small businesses. However, as stated by 
Fisher [1], Sharma [2] and Sharafat [3], the lack of efficient cost management methods in many sectors might do the agribusiness less competitive. Traditionally, cost management in small farms is usually only focused on direct costs and those related to operational activities, not supporting adequately decision making, thus, compromising business sustainability. In this context, we should highlight the supplier selection process because it compromises a significant amount of recurrent costs and ineffective decisions will impact in the short and long term households' financial sustainability [2].

Globally, family farming activities represent around $80 \%$ of the worldwide food production, involving approximately 570 million workers [4]. Thus, there are economic and social impacts from both a global and a local perspective which should be highlighted. The efforts made towards high levels of efficiency and cost reductions in this sector can be found worldwide. European Union countries, for instance, reduced spending on agricultural activities from approximately $70 \%$ in 1970 to $38 \%$ in 2018 , motivated by the use of modern agricultural management techniques [5] that significantly improved productivity. An important driver of this change was the implementation of the Common Agricultural Policy (CAP), which was based on protectionist policies. This policy has led to overproduction in the European Union since the 1980s, increasing the European budget through the provision of subsidies. Foreign producers protested against the strong protectionism of the EU, and this motivated internal and external pressures to reform the CAP [6]. In 1988, due to the high cost with agriculture subsidies, the EU reached its budget peak, almost reaching the financial breakthrough. This problem was solved by reducing agricultural subsidies but also costs in order to keep European agribusiness sustainable [7]. The result was the "Delors Package", which provided for further reductions in prices guaranteed by the CAP and a quota system to prevent overproduction [8].

Thus, cost management is fundamental in such a globalized sector. Studies like Seldon and Groenewald [9], among others, have proposed methodologies to calculate costs and profits in large-scale agricultural activities. However, these methodologies present limitations regarding their application to small and medium-sized agribusinesses. Largescale agribusiness companies commonly use expensive and sophisticated information and management systems [10] for planning strategic and operational goals. In many cases, production processes can be monitored through specific production software that provides individualized information by activity, area, crop and period, allowing the farm manager to know accurately products' costs and margins, and costs and profitability by other relevant cost objects (e.g., distribution channel) [10].

There is needed a very particular expertise, knowledge and practice for a good management of agribusinesses [11], nevertheless, these competencies are more developed in larger firms. In small agribusinesses, the analysis of performance and profitability is often based on empirical perceptions, without using management tools, software or any technology for data collection and/or to perform specialized analysis [12]. In general, small farms have not information and management systems and have not a good control of costs and revenues, depending on basic, ad-hoc and unstructured cost information and simplistic estimations, simple cost allocation procedures and subjective assumptions. However, owners' perceptions and expertise are valuable and constitute a good basis for the design of effective multi-criteria decision models tailored to these specific companies [2]. Such perceptions can be combined with the use of cost control methods and reliable and timely cost information which are also essential to support decision making for operational and strategic purposes [13], within more sophisticated decision-making systems [14]. Nowadays, the importance and feasibility of cost management is related to the quality of information and the access to cheaper technology to get, analyze and present the data. This leads to a better decision making and consequently, an effective and sustainable reduction in production costs.

In the literature, it is highlighted that family faming have, in general, a poor understanding about costs involved in the processes of raw materials acquisition, logistics, maintenance and storage [2,14]. In this context, the development of appropriate manage- 
ment cost models represents an important opportunity to improve the decision-making in agribusiness towards the financial sustainability of the company and also from a triplebottom perspective. Indeed, family farming has a significant economic but also social and environmental relevance locally, regionally and globally $[15,16]$.

Furthermore, there are several aspects on cost management related to family farming, such as the use of specific assets, seasonality of production, perishable products, variability in the production quality, small productive scale, and risks of agroindustry's monopolies and bargaining power that must be taken into account $[17,18]$. Commonly, these aspects are not fully considered in traditional costing methods used in agribusiness cost analysis. Furthermore, there are differences related to acquisition, reception, ownership, use, purchasing behavior, and disposal costs. Thus, it is necessary to design and use specific decision support tools which consider these specificities. This is particularly evident in the context of agriculture supply chain management and supplier selection process [19].

According to Degraeve et al. [20], supplier selection models are commonly simplistic, subjective and incomplete. Most of them focus on a weighted mean or use linear programming techniques-e.g., the Analytical Hierarchy Process (AHP) or Data Envelopment Analysis (DEA) methods, which consider only the compensatory aspect of the problem, and do not explore other related criteria. Moreover, these models are basically focused on the ranking of suppliers considering only acquisition costs [20-27]. However, these methods, such as AHP, must be better structured to establish correctly the preferences and the ranking of the alternatives considering the specificities of agribusiness, in general, and agribusiness and small farms, in particular.

According to Bronson et al. [12], profit margins of smallholder farmers have been decreasing over the years, and Bjorkhaug and Blekesaune [28] reported that the factors that contribute to the decrease in these margins are the saturation of arable areas, the increase in competition, the fall in product prices, the increasing in input costs and the decrease in agricultural subsidies. Furthermore, family farming generates low value-added production, whose price is low and stagnant, while input prices are gradually higher [29]. Moreover, Piedra-Muñoz et al. [30] demonstrated that the economic performance of family farming can be linked to socioeconomic and environmental innovation, but not yet closed to high levels of innovation, what can explain poor financial results and low products' margins. This has been contributing to the exodus to larger cities and more industrialized regions and countries, with social, economic and environmental consequences to local communities and regions $[12,28]$. Such changes contribute negatively to the quality and sustainability of agricultural products and generate social and economic inequalities that must be reverted.

Cost management is important for these companies and, according to Lips [31] and Degraeve and Roodhooft [21], inputs which are supplied recurrently represent the main expenses in the agribusiness sector. Nevertheless, some costs related to the acquisition of such inputs are mostly ignored, hidden or not easy to measure. In this context, the Total Cost of Ownership (TCO) concept allow to know better the full and real costs related to the acquisition of a particular good or service [22]. The use of TCO provides the understanding and recognition of all costs involved in the acquisition of raw materials and other inputs, namely, product transportation and storage, use and disposal, among others, including "hidden costs", not often recognized.

The lack of information certainly affects the efficient application of TCO, but it can be mitigated through farmers' experience captured by a multi-criteria approach. Therefore, the objective of this research is to fill the gap related to the design and application of cost management methodologies in family farming, aiming to increase assertiveness in decision making related to suppliers' selection and purchasing costs, through the use of a Total Cost of Ownership-Multiple Criteria Decision Analysis (TCO-MCDA) model, which combines the perspectives of TCO and multi-criteria analysis. The use of this model might provide significant financial benefits to smallholder farmers. 


\section{State of the Art}

\subsection{Cost Management and TCO in Family Farming}

Cost management is focused on acquisition of relevant information to assist stakeholders in management and decision making [32,33]. A good understanding of the behavior of materials and labor costs are particularly important in the implementation of a coherent cost management system in agriculture [34]. Cost management contributes to achieve higher levels of efficiency in two ways: (1) performing internal control, through monitoring of planned and realized costs; (2) assisting decision making through the analysis of production and accounting information considering the short and long-term [2,32].

TCO is very important in this context. TCO has been studied since the 1990s, mainly providing the identification of different costs related to the supplier selection process in the acquisition of inputs [21-23,35]. Thus, TCO can be categorized in dimensions like acquisition, services, commissioning, process, maintenance and disposal of a product or system $[27,36]$. In practice, TCO can be considered as the sum of actual and expected costs for supply, acquisition, transport, installation, ownership, use, maintenance, and disposal of the product, [26,37]. In this context, TCO is a relevant tool to help strategic cost management, providing efficiency in supplier assessment, and enabling a more efficient choice of supplies and services, going beyond the simplistic use of the purchase price as an absolute factor in decision making.

The use of TCO leads to a more complete costing approach, which considers the entire product life cycle, recognizing hidden costs, not always considered in traditional practices. Basically, TCO represents a monetary estimation of all related costs, direct and indirect [23]. The TCO is used in the purchasing process of manufacturing components [21,23], as well as to contract services in industrial environments $[38,39]$. TCO has been also used to analyze investment decisions and equipment alternatives considering all costs which are relevant, namely, those related to acquisition, operation and maintenance [40,41]. This use does not recognize returns, but rather, evaluates outputs in a more comprehensive and complete way, which is necessary for a more assertive investment analysis in agribusiness [42]. A TCO disadvantage is that it is not standardized. This fact means that TCO calculations cannot be compared. The same procedure and the same cost items would have to be considered to turn it possible. It is not even specified which cost items need to be included in the analysis. Commonly, cost items are selected according to the opinion of the experts involved in the analysis. Certain costs can be excluded from some analyses being considered unimportant items, while in another situation the same item may be considered very significant for the computation of the total cost. This variability and heterogeneity do not help the dissemination of TCO across companies and industries, spite its potential relevance and usefulness.

Table 1 presents the different applications of TCO, which can be extended for application in the agribusiness.

Table 1. TCO Applications.

\begin{tabular}{lc}
\hline \multicolumn{1}{c}{ Categories } & Authors \\
\hline Suppliers and Components & {$[20-27,43,44]$} \\
Services & {$[38,39]$} \\
Equipment and Processes & {$[31,36,37,40,45,46]$} \\
\hline
\end{tabular}

According to Scott et al. [47], TCO is the most comprehensive tool to obtain the total cost of inputs and services, in which all aspects related to the life cycle and maintenance costs are considered. Indeed, some authors claim that TCO has proven to be an efficient methodology to recognize all costs considering the entire company's value chain [23].

Often, TCO concepts are based on a strategy tripod: (1) improving supplier selection and acquisition processes; (2) identifying hidden costs, and (3) improving the management of products, equipment and internal processes. In agribusiness, cost management is essen- 
tially related to a better allocation of financial resources in animal and plant production, contributing to increased efficiency and competitiveness [2]. In this context, it can be influenced by external factors, such as climate and market [15].

Sharafat [3] concluded that there is an increasing need for the development of agricultural accounting in a more suitable way to control the farm activities, since agricultural management accounting provides important information for decision making. Nevertheless, Sharma [2] stated that management accounting in smallholder farmers has been not adequately developed and this fact can be one of the main reasons for the low productivity of such properties.

The use of TCO was mostly focused on industrial applications [38] and studies on costs in agribusiness are still scarce and incomplete [48]. Lips [31] proposed the use of TCO to evaluate the life cycle costs of tractors in Switzerland. Mochnacz et al. [44] also used TCO in the agribusiness environment by developing a TCO model that aimed to provide significant cost savings by assessing all costs incurred in the acquisition of inputs and services. Regarding the assessment of all life cycle costs, Hofman-Caris et al. [49] analyzed the TCO in a rainwater harvesting system for rural properties.

Shabani et al. [43] developed a Data Envelopment Analysis (DEA) methodology based on the TCO, to try to reduce data and traditional models' inaccuracy, which prevent the small farmers from reaching significant savings.

\subsection{Multi-Criteria Methods Applied in Agribusiness}

Multi-criteria analysis is a widely used methodology which evaluates alternatives and criteria for different stakeholder groups [50]. The main advantage of this methodology is the recognition of qualitative criteria, which are not easily measured. It also provides the integration among diverse areas, considers alternatives that may be ranked, selected or sorted, in order to optimize the decision-making process [51,52].

Usually, multi-criteria methods incorporate three distinct aspects related to the decision makers' preferences [53]. First, they allow considering several points of view aggregated in a single analysis. Second, they turn possible to solve problems with multiple objectives, which require a systematized procedure. Third, results are presented into a set of alternatives arising from paired comparisons between multiple alternatives [53,54].

According to Tsoukiás [51] and Komeleh et al. [55], the multi-criteria methodologies are totally adherent to the applications in the agricultural sector, and are particularly appropriated to assist family farming [56]. Some of these studies have a focus on prioritizing production activities, energy efficiency and reusing of resources [55]. Decision models with various criteria can be used for various purposes. For example, allocating agricultural areas for planting as presented by Kaim et al. [56], and for optimizing fuel economy in heavy trucks, using TCO as one of the criteria, as Fries et al. [57].

Some authors integrate environmental aspects in multi-criteria models, like Fagioli et al. [58]. They present an aggregate methodology to assess the olive oil food value chain, using the ELECTRE III multi-criteria method. Louwagie et al. [59] evaluated the environmental footprint in the production of pastures for dairy and beef cattle using multi-criteria methods. García et al. [60] used the AHP (Analytic Hierarchy Process) method to evaluate optimal locations of agro-food warehouses through a case study of a banana distribution warehouse.

Oliveira et al. [61] also used the AHP method to hierarchize milk production systems regarding their sustainability, through a cluster analysis, considering 92 milk producers. Castro Silva et al. [54] proposed a decision-making model based on the PROMETHEE II method to provide feasible alternatives to improve organizational management in production and marketing of fruit cultivation.

Hall et al. [62] applied the AHP method to evaluate the evidence of public policies in the agriculture sector, recognized by the population. Depending on the complexity presented by the problem, a hybrid combination of methods, involving multi-criteria analysis can contribute significantly to improve the decision-making process [63]. 


\section{Materials and Methods}

The methodological foundations of the proposed model are organized in seven phases describing a combined TCO and Multi-Criteria Decision Model (TCO-MCDM), as illustrated in Figure 1.

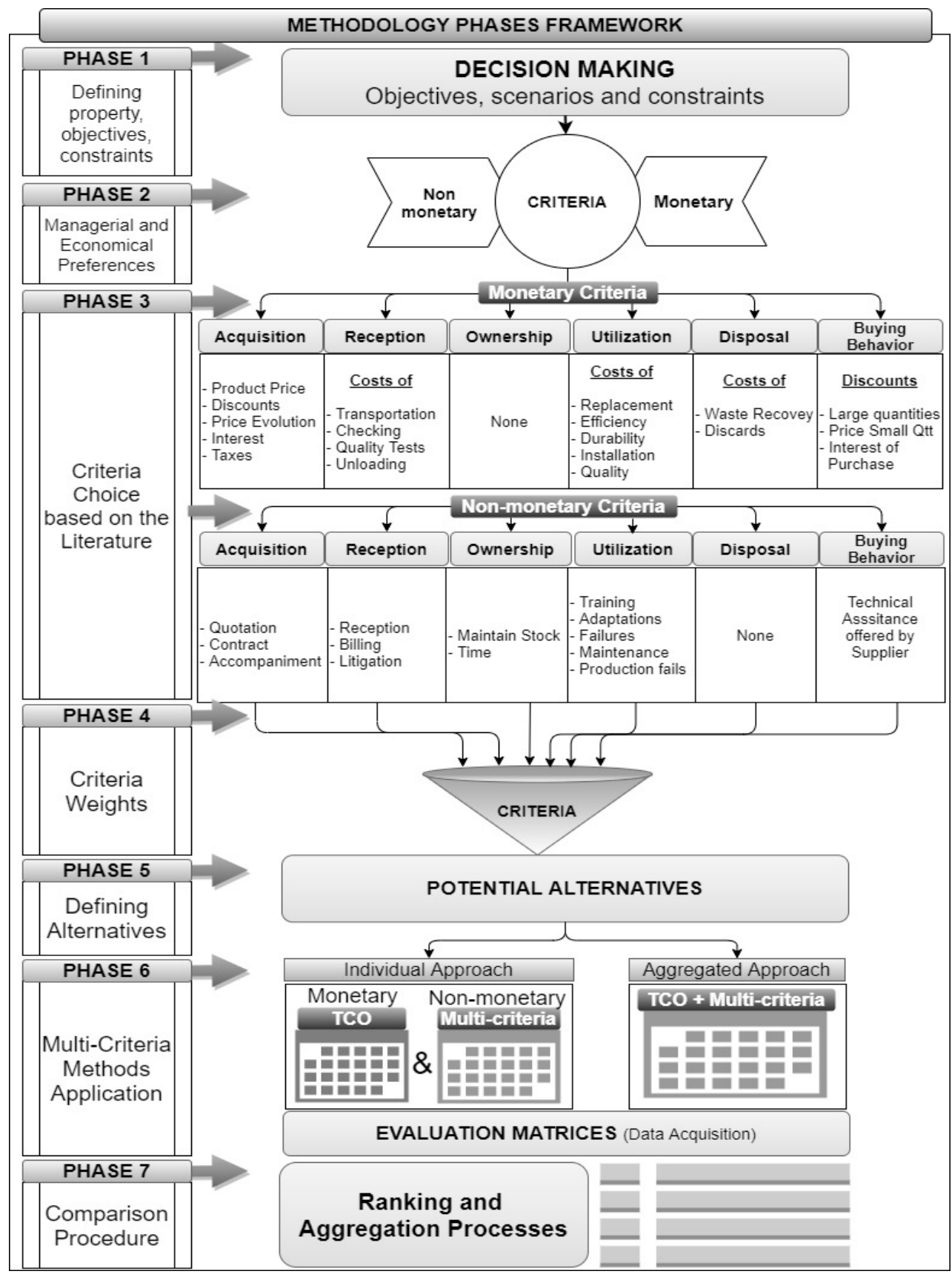

Figure 1. TCO-MCDM Model.

This model presents a methodology to select suppliers for smallholder farmers, considering the TCO criteria selected from the literature and suitable to each application, through an appropriate acquisition data procedure in smallholder farmers.

Although the model uses complex cost management and multi-criteria concepts, it could be presented in a computational application to the users (e.g., smallholder farmers), and this complexity bypassed through a user-friendly software. Next, the seven phases of the model are explained in detail. 
Phase 1 encompasses the identification of the characteristics and most relevant features, monetary limitations, available areas, and long-term objectives. In Phase 2, it is necessary to identify the objectives to be achieved. For example, if owners are interested in increasing their market share or investing in the farm.

The definition of the global criteria is performed in the third stage, based on scientific information. The results obtained in this case were 31 criteria commonly used in the agribusiness context.

In Phase 4, a questionnaire is applied to the decision makers, in order to define the priority criteria, considering the five evaluation steps proposed by Degraeve, et al. [20], namely, "cash" versus "non-cash" criteria, which we call here "monetary" and "nonmonetary", respectively. In Phase 5, the potential suppliers are listed as alternatives. In Phase 6, the alternatives are compared (1) from a TCO approach, in which the best supplier is the one that has the lowest (complete) cost; (2) from a multi-criteria approach, where non-monetary characteristics and respective weights are considered, and in which not necessarily the supplier with the lowest total cost are the best choice; and (3) considering a combined TCO+MCDA approach.

The multi-criteria MABAC (Multi-Attributive Border Approximation area Comparison) method is used to perform the ranking of the alternatives in this phase. Finally, in Phase 7, the results of the different approaches are compared, in order to drive coherently decision-making for family farming.

\section{Analysis of Results}

The model was applied to the case of soybean production, in which three inputs represent approximately two thirds of the production costs: seeds, chemical fertilizers and fungicides. The data was collected in 33 smallholder farmers properties in a region located in the West of the Santa Catarina State, Brazil. This region has an important concentration of household properties, which indirectly supplies the national food market in Brazil [64]. To simplify the presentation of the Tables just one input is illustrated. The calculations performed for the other inputs are presented in the attached supplementary document (Tables S1-S19). Considering the different characteristics of the three inputs, the proposed model helps to minimize the variability of the data.

\subsection{Phases 1 to 4-Defining preferences, objectives and constraints, and evaluation criteria}

A questionnaire was applied to the owners of the small farmers in order to define their preferences, objectives and constraints.

The questionnaire was sent to 58 household properties and 33 answers were returned. These questionnaires asked the farmers' opinion about 33 criteria (shown in column 2 of Table 2). All the properties that were surveyed are managed by farmers and their families, being categorized as family farming by IBGE [64].

The data collection considered 11 suppliers of the three types of inputs (seeds, fertilizers and fungicides). These suppliers were selected because all of them provided the three inputs surveyed, in order to avoid the limitation of the exclusivity of supplying certain types of inputs. Soybean is particularly important because it is one of the main crops produced in the world, and Brazil is the second largest producer of this grain [65]. From these 11 suppliers, information regarding the 33 criteria in Table 2 was obtained, only for the 3 products surveyed (seeds, fertilizers and fungicides).

The global criteria were defined from the literature review on TCO presented in Table 2 (the weights for the different criteria are presented in the supplementary document (Tables S1-S19)). For the selection of the specific criteria, the answers to the questionnaire were considered along with six dimensions of analysis, five of them following those proposed by Degraeve et al. [20], i.e., Acquisition, Reception, Ownership, Utilization, Disposal and an additional one to represent the purchasing behavior. The dimensions and criteria were compared in pairs, where the farmer should assign a score of importance for the different costs from 1 to 5 , ranging from equally important to absolutely more important, 
respectively, according to an adapted Saaty's scale: (1) Equally important; (2) It is just a little more important; (3) It is more important; (4) Strongly more important; and (5) Absolutely more important. After the acquisition of the individual answers, the criteria weights were composed computing the median of the responses from the 33 farms studied. From that, a ranking of importance (weights) for the six dimensions was elaborated. It should be noted that only operating costs were considered. Investment costs were not included into the analysis. The main criteria often used in agribusiness assessments, according to the TCO approach are presented in Table 2.

Table 2. Weights for TCO-Criteria (based on the literature).

\begin{tabular}{|c|c|c|c|c|}
\hline Rank & Criteria & Dimension & Characteristic & Weight \\
\hline 1 & Product Price & Acquisition & Monetary & $4.34 \%$ \\
\hline 2 & Discounts & Acquisition & Monetary & $4.01 \%$ \\
\hline 3 & Efficiency & Utilization & Monetary & $3.84 \%$ \\
\hline 4 & Durability & Utilization & Monetary & $3.81 \%$ \\
\hline 5 & Transportation & Reception & Monetary & $3.68 \%$ \\
\hline 6 & Price Evolution & Acquisition & Monetary & $3.58 \%$ \\
\hline 7 & Interest of Purchase & Buying behaviour & Monetary & $3.43 \%$ \\
\hline 8 & Unloading & Reception & Monetary & $3.35 \%$ \\
\hline 9 & Taxes & Acquisition & Monetary & $3.33 \%$ \\
\hline 10 & Failures & Utilization & Non-Monetary & $3.14 \%$ \\
\hline 11 & Replacement & Utilization & Monetary & $3.13 \%$ \\
\hline 12 & Failures & Utilization & Non-Monetary & $3.12 \%$ \\
\hline 13 & Reception & Reception & Non-Monetary & $3.05 \%$ \\
\hline 14 & Quotation & Acquisition & Non-Monetary & $3,00 \%$ \\
\hline 15 & Contract & Acquisition & Non-Monetary & $2.89 \%$ \\
\hline 16 & Billing & Reception & Non-Monetary & $2.89 \%$ \\
\hline 17 & Maintain stock & Ownership & Monetary & $2.85 \%$ \\
\hline 18 & Time & Ownership & Non-Monetary & $2.85 \%$ \\
\hline 19 & Checking & Reception & Monetary & $2.82 \%$ \\
\hline 20 & Adaptations & Utilization & Non-Monetary & $2.78 \%$ \\
\hline 21 & Price small quantities & Buying behaviour & Monetary & $2.76 \%$ \\
\hline 22 & Accompaniment & Acquisition & Non-Monetary & $2.75 \%$ \\
\hline 23 & Quality tests & Reception & Monetary & $2.75 \%$ \\
\hline 24 & Waste recovery & Disposal & Monetary & $2.73 \%$ \\
\hline 25 & Maintenance & Utilization & Non-Monetary & $2.70 \%$ \\
\hline 26 & Litigation & Reception & Non-Monetary & $2.67 \%$ \\
\hline 27 & Discards & Disposal & Monetary & $2.65 \%$ \\
\hline 28 & Installation & Utilization & Monetary & $2.65 \%$ \\
\hline 29 & Large Quantities & Buying behaviour & Monetary & $2.64 \%$ \\
\hline 30 & Interest & Acquisition & Monetary & $2.53 \%$ \\
\hline 31 & Training & Utilization & Non-Monetary & $2.46 \%$ \\
\hline 32 & Quality & Utilization & Monetary & $2.43 \%$ \\
\hline \multirow[t]{2}{*}{33} & Tech. assistance by supplier & Buying behaviour & Non-Monetary & $2.39 \%$ \\
\hline & & & & $100.00 \%$ \\
\hline
\end{tabular}

Source: Adapted from Degraeve; Roodhooft; Doveren [25].

An individual data collection for each farm was carried out, in order to adjust the criteria to the context, taking into account the activities performed in each case, also helping to determine the particular criteria detailed in Table 3. Furthermore, Table 4 presents the input matrix for the acquisition of the Chemical Fertilizer, as an example. To do this, we considered the principles stated by Degraeve et al. [20], which presented a hierarchical matrix for the management of manufacturing, marketing, and research and development costs. From the six dimensions of analysis related to the 33 criteria of the model, only three are in the ranking of the 15 most relevant criteria, which are: Acquisition, Use and Reception. Furthermore, there are specific criteria that represent farmers' preferences, allowing the prioritization of issues in the evaluation process. Moreover, the six top criteria in this ranking are non-monetary, justifying the adoption of a Multi-criteria Decision Analysis model (MCDA). These criteria are described in detail in Table 3. 
Table 3. Selection of specific Criteria.

\begin{tabular}{|c|c|c|c|c|c|}
\hline Criteria & Abbreviation & Characteristic & Description & $\begin{array}{c}\text { Unit of } \\
\text { Measurement }\end{array}$ & Example \\
\hline 1. Product Price & PPR & Monetary & Price of the product, informed by suppliers & Value (USD) & Monetary value (USD) \\
\hline 2. Discount & DIS & Monetary & $\begin{array}{l}\text { Reduction on the price, offered as a differential } \\
\text { for sales }\end{array}$ & Value (USD) & Percentage (\%) based on quantity purchased \\
\hline 3. Efficiency & EFF & Monetary & $\begin{array}{l}\text { Cost necessary to maintain efficiency } \\
\text { of operations }\end{array}$ & Cost Value (USD) & Training and stocking costs \\
\hline 4. Durability & DUR & Monetary & Cost to guarantee the durability of the products & Cost Value (USD) & Storage and setting costs \\
\hline 6. Price Evolution & PEV & Monetary & Difference of product price in a period of time & Value (USD) in 30 days & Periodic increasing of prices, taxes, or fees \\
\hline 7. Production Fails & CPRF & Non-Monetary & $\begin{array}{l}\text { Score of relevance for costs related to } \\
\text { production failure }\end{array}$ & $\begin{array}{l}\text { Intensity } \\
\text { (Saaty scale) }\end{array}$ & Failure that causes production losses \\
\hline 8. Failures & $\mathrm{CPF}$ & Non-Monetary & $\begin{array}{l}\text { Score of relevance for costs related to } \\
\text { product failure }\end{array}$ & $\begin{array}{l}\text { Intensity } \\
\text { (Saaty scale) }\end{array}$ & Failure that causes monetary losses \\
\hline 9. Reception & COR & Non-Monetary & $\begin{array}{l}\text { Score of relevance for costs related to activities } \\
\text { related to the reception of products }\end{array}$ & $\begin{array}{l}\text { Intensity } \\
\text { (Saaty scale) }\end{array}$ & Special place to storage the products \\
\hline 10. Quotation & $\mathrm{CQO}$ & Non-Monetary & $\begin{array}{l}\text { Score of relevance for costs related to price } \\
\text { quotation activities }\end{array}$ & $\begin{array}{l}\text { Intensity } \\
\text { (Saaty scale) }\end{array}$ & People assigned to realize quotation activities \\
\hline 11. Contract & $\mathrm{CCO}$ & Non-Monetary & $\begin{array}{l}\text { Score of relevance for costs related to contracts } \\
\text { management activities }\end{array}$ & Intensity of risk (Saaty scale) & $\begin{array}{l}\text { People assigned to realize contracts } \\
\text { management activities }\end{array}$ \\
\hline $\begin{array}{l}\text { 12. Technical Assistance } \\
\text { Offered by the Supplier }\end{array}$ & TAS & Non-Monetary & $\begin{array}{l}\text { Existence or absence of free technical assistance } \\
\text { offered by the supplier }\end{array}$ & $\begin{array}{l}\text { Existent or } \\
\text { Not Existent }\end{array}$ & Free training on the use of the product \\
\hline
\end{tabular}


Table 4. Input Matrix for Product Chemical Fertilizer.

\begin{tabular}{|c|c|c|c|c|c|c|c|c|c|c|c|c|}
\hline $\begin{array}{c}\text { Criteria/ } \\
\text { Alternatives }\end{array}$ & Product Price & Discount & Efficiency & Durability & Transportation & Price Evolution & Production Fails & Failures & Reception & Quotation & Contract & $\begin{array}{c}\text { Technical } \\
\text { Assistance }\end{array}$ \\
\hline Abbreviation & PPR & DISC & EFF & DUR & TRC & PEV & CPRF & $\mathrm{CPF}$ & COR & $\mathrm{CQO}$ & $\mathrm{CCO}$ & TAS \\
\hline Unit & USD & USD & USD & USD & USD & USD & score & score & score & score & score & $\mathrm{Y} / \mathrm{N}$ \\
\hline S-2 & 21.3 & 0.21 & 1.30 & 0.53 & 0.10 & 0.25 & 3 & 3 & 3 & 1 & 3 & 1 \\
\hline S-3 & 20.4 & 0.20 & 1.24 & 0.51 & 0.00 & 0.20 & 3 & 3 & 3 & 1 & 3 & 0 \\
\hline S-4 & 21.0 & 0.31 & 1.28 & 0.53 & 0.00 & 0.00 & 7 & 5 & 3 & 1 & 5 & 0 \\
\hline S-5 & 20.3 & 0.00 & 1.24 & 0.51 & 0.40 & 0.20 & 5 & 5 & 3 & 5 & 3 & 1 \\
\hline S-6 & 20.0 & 0.00 & 1.22 & 0.50 & 0.50 & 0.00 & 5 & 5 & 3 & 3 & 3 & 1 \\
\hline S-8 & 20.8 & 0.00 & 1.27 & 0.52 & 0.50 & 0.42 & 5 & 3 & 5 & 3 & 3 & 0 \\
\hline S-9 & 19.5 & 0.19 & 1.19 & 0.49 & 0.50 & 0.00 & 3 & 3 & 3 & 5 & 1 & 1 \\
\hline S-10 & 20.4 & 0.20 & 1.24 & 0.51 & 0.00 & 0.00 & 3 & 3 & 3 & 5 & 3 & 1 \\
\hline S-11 & 20.0 & 0.00 & 1.22 & 0.50 & 0.30 & 0.00 & 3 & 1 & 3 & 3 & 3 & 1 \\
\hline
\end{tabular}


The evaluation of non-monetary criteria was based on the Saaty' Scale with 5 categories and their respective scores of relevance, which are: (a) Non-relevant cost (score 1); (b) Cost with small relevance (score 3); (c) Cost with medium relevance (score 5); (d) Cost with high relevance (score 7); and (e) Cost with absolute relevance (score 9). For the non-monetary criterion "Technical assistance offered by supplier" it was used a binary scale; i.e., " 0 " when the supplier does not offer free technical assistance and " 1 " when such assistance is provided.

After collecting the non-monetary data, the weights were listed using the AHP method, to define the most relevant weights according to the opinion of the farmers.

The data from different scales were normalized, but it was not possible to calculate the consistency ratio from AHP formulations because the weights were calculated by the difference between the sum of the values in rows and columns (shown in next section). It is obtained more accuracy on the weight determination when the difference between the intensity of victories and defeats from pairwise comparisons is considered; instead of the traditional procedure used in the AHP method, which only considers the rows (victories) to calculate the weights and columns to calculate the consistency ratio.

\subsection{Phase 5-TCO-based and Multi-criteria Decision Model}

The potential alternatives (i.e., suppliers) were evaluated in each of the 12 specific criteria. Table 4 presents the data collected for the 12 criteria and the 11 suppliers related to the chemical fertilizer; the information on the other inputs is presented in a supplementary document.

Two different rankings (Tables 5 and 6) were produced considering separately the 6 monetary and the 6 non-monetary criteria which were aggregated by average in Table 7.

Table 5. Evaluation of Monetary Criteria for Chemical Fertilizer.

\begin{tabular}{|c|c|c|c|c|c|c|c|c|}
\hline $\begin{array}{l}\text { Criteria/ } \\
\text { Alternatives }\end{array}$ & Product Price & Discount & Efficiency & Durability & Transportation & Price Evolution & \multirow{3}{*}{$\begin{array}{l}\text { SUM } \\
\sum_{i=1}^{n} v_{i} \\
\text { USD }\end{array}$} & Ranking \\
\hline Abbreviation & PPR & DISC & EFF & DUR & TRC & PEV & & $\operatorname{Rank}=\min \left(\sum_{i=1}^{\infty} v_{i}\right)$ \\
\hline Unit & USD & USD & USD & USD & USD & USD & & \\
\hline S-1 & 20.00 & 0.00 & 1.22 & 0.50 & 0.00 & 0.40 & 22.12 & 4 th \\
\hline S-2 & 21.30 & -0.21 & 1.30 & 0.53 & 0.10 & 0.25 & 23.27 & 10th \\
\hline$S-3$ & 20.40 & -0.20 & 1.24 & 0.51 & 0.00 & 0.20 & 22.15 & 5 th \\
\hline S-4 & 21.00 & -0.31 & 1.28 & 0.53 & 0.00 & 0.00 & 22.50 & 7 th \\
\hline S-5 & 20.30 & 0.00 & 1.24 & 0.51 & 0.40 & 0.20 & 22.65 & 8 th \\
\hline S-6 & 20.00 & 0.00 & 1.22 & 0.50 & 0.50 & 0.00 & 22.22 & 6th \\
\hline S-7 & 20.50 & 0.00 & 1.25 & 0.51 & 0.50 & 0.25 & 23.01 & 9th \\
\hline S-8 & 20.80 & 0.00 & 1.27 & 0.52 & 0.50 & 0.42 & 23.51 & 11th \\
\hline S-9 & 19.50 & -0.19 & 1.19 & 0.49 & 0.50 & 0.00 & 21.49 & $1 \mathrm{st}$ \\
\hline S-10 & 20.40 & -0.20 & 1.24 & 0.51 & 0.00 & 0.00 & 21.95 & 2nd \\
\hline S-11 & 20.00 & 0.00 & 1.22 & 0.50 & 0.30 & 0.00 & 22.02 & $3 \mathrm{rd}$ \\
\hline
\end{tabular}

Table 6. Evaluation of Non-Monetary Criteria for Chemical Fertilizer.

\begin{tabular}{|c|c|c|c|c|c|c|c|}
\hline $\begin{array}{l}\text { Criteria/ } \\
\text { Alternatives }\end{array}$ & Production Fails & Failures & Reception & Quotation & Contract & Technical Assistance & Ranking \\
\hline Abbreviation & CPRF & CPF & COR & CQO & $\mathrm{CCO}$ & TAS & $R_{K}=\min \left(\sum^{n} w_{j} * v_{i j}\right.$ \\
\hline Weight $\left(w_{j}\right)$ & $16.66 \%$ & $16.67 \%$ & $16.67 \%$ & $16.67 \%$ & $16.67 \%$ & $16.66 \%$ & 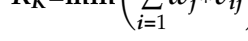 \\
\hline Unit & Score & Score & Score & Score & Score & $\mathbf{Y} / \mathbf{N}$ & \\
\hline S-1 & 3 & 1 & 3 & 1 & 3 & 1 & 1 st \\
\hline S-2 & 3 & 3 & 3 & 1 & 3 & 1 & 2nd \\
\hline S-3 & 3 & 3 & 3 & 1 & 3 & 0 & $3 \mathrm{rd}$ \\
\hline S-4 & 7 & 5 & 3 & 1 & 5 & 0 & 10th \\
\hline S-5 & 5 & 5 & 3 & 5 & 3 & 1 & 9th \\
\hline S-6 & 5 & 5 & 3 & 3 & 3 & 1 & 7 th \\
\hline S-7 & 7 & 5 & 5 & 3 & 3 & 0 & 11th \\
\hline S-8 & 5 & 3 & 5 & 3 & 3 & 0 & 8 th \\
\hline S-9 & 3 & 3 & 3 & 5 & 1 & 1 & 5 th \\
\hline S-10 & 3 & 3 & 3 & 5 & 3 & 1 & 6th \\
\hline S-11 & 3 & 1 & 3 & 3 & 3 & 1 & 4th \\
\hline
\end{tabular}


Table 7. Aggregated Ranking for Chemical Fertilizer.

\begin{tabular}{cccc}
\hline Alternatives & Ranking Monetary (RM) & $\begin{array}{c}\text { Ranking } \\
\text { Non-Monetary (RE) }\end{array}$ & $\begin{array}{c}\text { Final Ranking by } \\
\text { Average RM and RE }\end{array}$ \\
\hline S-1 & 4 th & 1 st & 1 st \\
S-2 & 10 th & 2 nd & 6 th \\
S-3 & 5 th & 3 rd & 5 th \\
S-4 & 7 th & 10 th & 8 th \\
S-5 & 8 th & 9 th & 9 th \\
S-6 & 6th & 7 th & 7 th \\
S-7 & 9 th & 11 th & 11 th \\
S-8 & 11 th & 8 th & 10 th \\
S-9 & 1st & 5 th & 2 nd \\
S-10 & 2nd & 6 th & 4 th \\
S-11 & 3rd & 4 th & 3 rd \\
\hline
\end{tabular}

Table 6 presents the MCDM procedure for ranking alternatives with the nonmonetary criteria.

Furthermore, the weights for the 12 specific criteria were calculated. Just eight criteria are presented as an example in Table 8. The difference between columns and rows was considered after the sum of the scores given by the decision makers, based on the Saaty's scale. This procedure was also adopted for the calculation of the weights of the dimensions, shown in Table 9.

\subsection{Phase 6-Ranking of the Suppliers Using the Multi-Criteria MABAC Method}

The basis of the MABAC method is seen in the definition of the distance of the criterion function of each alternative from the border approximation area. This method was applied considering the 6 steps proposed by Pamucar and Cirovic [66].

MABAC-Step 1: definition of the evaluation decision matrix $(X)$.

The data collected through interviews with farmers were tabulated, forming the evaluation matrix for Chemical Fertilizer. Table 10 shows the averages of all respondents (values in USD and Saaty scores).

MABAC-Step 2: Normalization of the elements in the global evaluation matrix $(X)$, by the $\mathrm{max} / \mathrm{min}$ linear normalization.

$$
\text { Benefit }=n_{i j}=\frac{x_{i j}-x_{i j}^{-}}{x_{i j}^{+}-x_{i j}^{-}} ; \text {Cost }=n_{i j}=\frac{x_{i j}-x_{i j}^{+}}{x_{i j}^{-}-x_{i j}^{+}}
$$

MABAC-Step 3: Calculation of weighted matrix elements $(V)$. The elements from the weighted matrix $(V)$ are calculated based on Equation (2).

$$
V_{i j}=w_{i} *\left(n_{i j}+1\right)
$$

MABAC-Step 4: Determination of the border approximation area matrix $(G)$. The border approximation area for each criterion is determined according to Equation (3).

$$
G_{i}=\left(\prod_{j=1}^{m} v_{i j}\right)^{\frac{1}{m}}
$$

MABAC-Steps 5 and 6: Calculation of the distance of each alternative from the border matrix elements $(Q)$ and Ranking of alternatives.

$$
Q=V-G
$$

The Calculation of matrix $Q$ and Final Ranking are presented in Table 11. 
Table 8. Global Criteria Weight Evaluation (scale 1 to 5).

\begin{tabular}{|c|c|c|c|c|c|c|c|c|c|c|c|}
\hline & \multicolumn{11}{|c|}{ ATTRIBUTES OF DIMENSION ACQUISITION } \\
\hline & Product Price & Discount & Price Evolution & Interest of Purchase & Taxes & Quotation & Contract & Accompaniment & $\begin{array}{c}\text { SRows } \\
\sum_{i=1}^{n} v_{i}\end{array}$ & $\begin{array}{c}\text { Score } \\
Y_{i}=w_{j}^{*}(100+Z)\end{array}$ & $\begin{array}{l}\text { Weights } \\
w_{j}=\frac{Y_{i}}{\sum_{i=1}^{n} v_{i}}\end{array}$ \\
\hline Discount & 0.25 & 1.00 & 3.00 & 4.00 & 4.00 & 4.00 & 4.00 & 4.00 & 24.25 & 22.86 & $14.71 \%$ \\
\hline Price Evolution & 0.25 & 0.33 & 1.00 & 2.00 & 2.00 & 3.00 & 3.00 & 3.00 & 14.58 & 20.32 & $13.07 \%$ \\
\hline Interest of Purchase & 0.25 & 0.25 & 0.50 & 1.00 & 2.00 & 3.00 & 3.00 & 3.00 & 13.00 & 19.53 & $12.56 \%$ \\
\hline Taxes & 0.25 & 0.25 & 0.50 & 0.50 & 1.00 & 3.00 & 3.00 & 3.00 & 11.50 & 18.94 & $12.19 \%$ \\
\hline Quotation & 0.25 & 0.25 & 0.33 & 0.33 & 0.33 & 1.00 & 2.00 & 2.00 & 6.50 & 17.00 & $10.94 \%$ \\
\hline Monitoring & 0.20 & 0.25 & 0.33 & 0.33 & 0.33 & 0.50 & 0.50 & 1.00 & 3.45 & 15.63 & $10.06 \%$ \\
\hline SColumns & 2.70 & 6.58 & 10.00 & 12.50 & 14.00 & 19.00 & 20.50 & 23.00 & & 155.44 & $100.00 \%$ \\
\hline$Z=$ SRows - SColumns & 27.30 & 17.67 & 4.58 & 0.50 & -2.50 & -12.50 & -15.50 & -19.55 & & & \\
\hline
\end{tabular}

Table 9. Weights of the Dimensions (scale 1 to 5).

\begin{tabular}{|c|c|c|c|c|c|c|c|c|c|}
\hline & \multicolumn{9}{|c|}{ GLOBAL DIMENSIONS } \\
\hline & Acquisition & Reception & Ownership & Utilization & Disposal & Buying Behaviour & $\begin{array}{c}\text { SRows } \\
\sum_{i=1}^{n} v_{i}\end{array}$ & $\begin{array}{c}\text { Score } \\
Y_{i}=100+Z\end{array}$ & $\begin{array}{l}\text { Weights } \\
w_{j}=\frac{\Upsilon_{i}}{\sum_{i=1}^{n} v_{i}}\end{array}$ \\
\hline Reception & 0.25 & 1.00 & 2.00 & 2.00 & 2.00 & 3.00 & 10.25 & 103.42 & $17.24 \%$ \\
\hline Ownership & 0.33 & 0.50 & 1.00 & 0.50 & 2.00 & 2.00 & 6.33 & 97.33 & $16.22 \%$ \\
\hline Utilization & 0.33 & 0.50 & 2.00 & 1.00 & 3.00 & 3.00 & 9.83 & 102.67 & $17.11 \%$ \\
\hline Disposal & 0.25 & 0.50 & 0.50 & 0.33 & 1.00 & 2.00 & 4.58 & 92.08 & $15.35 \%$ \\
\hline SColumns & 2.42 & 6.83 & 9.00 & 7.17 & 12.50 & 15.00 & & 600.00 & $100.00 \%$ \\
\hline $\mathrm{Z}=$ SRows - SColumns & 16.58 & 3.42 & -2.67 & 2.67 & -7.92 & -12.08 & & & \\
\hline
\end{tabular}


Table 10. Global Evaluation Matrix (X) for Chemical Fertilizer.

\begin{tabular}{|c|c|c|c|c|c|c|c|c|c|c|c|c|}
\hline Criteria/Alternatives & Product Price & Discount & Efficiency & Durability & Transportation & Price Evolution & Production Fail & Failures & Reception & Quotation & Contract & Technical Assistance \\
\hline Weight (\%) & 10.65 & 9.84 & 9.42 & 9.34 & 9.00 & 8.75 & 7.7 & 7.64 & 7.47 & 7.32 & 7.07 & 5.8 \\
\hline Abbreviation & PPR & DISC & EFF & DUR & TRC & PEV & CPRF & $\mathrm{CPF}$ & COR & $\mathrm{CQO}$ & $\mathrm{CCO}$ & TAS \\
\hline Unit & USD & USD & USD & USD & USD & USD & score & score & score & score & score & $\mathrm{Y} / \mathrm{N}$ \\
\hline Direction & Bnf. & Cost & Bnf. & Bnf. & Bnf. & Bnf. & Bnf. & Bnf. & Bnf. & Bnf. & Bnf. & Cost \\
\hline S-1 & 20.00 & 0.00 & 1.22 & 0.50 & 0.00 & 0.40 & 3 & 1 & 3 & 1 & 3 & 1 \\
\hline S-2 & 21.30 & 0.21 & 1.30 & 0.53 & 0.10 & 0.25 & 3 & 3 & 3 & 1 & 3 & 1 \\
\hline S-3 & 20.40 & 0.20 & 1.24 & 0.51 & 0.00 & 0.20 & 3 & 3 & 3 & 1 & 3 & 0 \\
\hline S-4 & 21.00 & 0.31 & 1.28 & 0.53 & 0.00 & 0.00 & 7 & 5 & 3 & 1 & 5 & 0 \\
\hline S-5 & 20.30 & 0.00 & 1.24 & 0.51 & 0.40 & 0.20 & 5 & 5 & 3 & 5 & 3 & 1 \\
\hline S-7 & 20.50 & 0.00 & 1.25 & 0.51 & 0.50 & 0.25 & 7 & 5 & 5 & 3 & 3 & 0 \\
\hline S-8 & 20.80 & 0.00 & 1.27 & 0.52 & 0.50 & 0.42 & 5 & 3 & 5 & 3 & 3 & 0 \\
\hline S-9 & 19.50 & 0.19 & 1.19 & 0.49 & 0.50 & 0.00 & 3 & 3 & 3 & 5 & 1 & 1 \\
\hline S-10 & 20.40 & 0.20 & 1.24 & 0.51 & 0.00 & 0.00 & 3 & 3 & 3 & 5 & 3 & 1 \\
\hline S-11 & 20.00 & 0.00 & 1.22 & 0.50 & 0.30 & 0.00 & 3 & 1 & 3 & 3 & 3 & 1 \\
\hline
\end{tabular}

Table 11. Calculation of matrix $Q$ and Final Ranking.

\begin{tabular}{|c|c|c|c|c|c|c|c|c|c|c|c|c|c|c|}
\hline Cr/Alt. & Product Price & Discount & Efficiency & Durability & Transportation & Price Evolution & Production Fail & Failures & Reception & Quotation & Contract & Technical Assistance & $\sum S_{i}$ & Ranking \\
\hline S-1 & 0.03 & -0.03 & 0.02 & 0.03 & 0.05 & -0.05 & 0.03 & 0.05 & 0.02 & 0.04 & 0.00 & 0.02 & 0.20 & 4th \\
\hline S-2 & -0.05 & 0.04 & -0.05 & -0.04 & 0.03 & -0.02 & 0.03 & 0.01 & 0.02 & 0.04 & 0.00 & 0.02 & 0.03 & 7th \\
\hline S-3 & 0.00 & 0.04 & 0.00 & 0.00 & 0.05 & 0.00 & 0.03 & 0.01 & 0.02 & 0.04 & 0.00 & 0.02 & 0.21 & 2nd \\
\hline S-4 & -0.03 & 0.07 & -0.03 & -0.04 & 0.05 & 0.04 & -0.05 & -0.03 & 0.02 & 0.04 & -0.03 & -0.04 & -0.04 & 8th \\
\hline S-5 & 0.01 & -0.03 & 0.00 & 0.00 & -0.02 & 0.00 & -0.01 & -0.03 & 0.02 & -0.04 & 0.00 & 0.02 & -0.07 & 9th \\
\hline S-6 & 0.03 & -0.03 & 0.02 & 0.03 & -0.04 & 0.04 & -0.01 & -0.03 & 0.02 & 0.00 & 0.00 & 0.02 & 0.05 & 6th \\
\hline S-7 & 0.00 & -0.03 & 0.00 & 0.00 & -0.04 & -0.02 & -0.05 & -0.03 & -0.06 & 0.00 & 0.00 & -0.04 & -0.26 & 10th \\
\hline $\mathrm{S}-8$ & -0.02 & $\begin{array}{l}-0.03 \\
-0.03\end{array}$ & -0.02 & $\begin{array}{l}0.00 \\
-0.02\end{array}$ & $\begin{array}{l}-0.04 \\
-0.04\end{array}$ & $\begin{array}{l}-0.02 \\
-0.05\end{array}$ & -0.01 & 0.01 & -0.06 & 0.00 & 0.00 & $\begin{array}{l}-0.04 \\
-0.04\end{array}$ & -0.27 & 11th \\
\hline S-9 & 0.05 & 0.03 & 0.05 & $\begin{array}{l}0.05 \\
0.05\end{array}$ & $\begin{array}{l}-0.04 \\
-0.04\end{array}$ & 0.04 & 0.03 & 0.01 & 0.02 & -0.04 & 0.04 & 0.02 & 0.26 & $1 \mathrm{st}$ \\
\hline S-10 & 0.00 & 0.04 & 0.00 & 0.00 & 0.05 & 0.04 & 0.03 & 0.01 & 0.02 & -0.04 & 0.00 & 0.02 & 0.18 & 5th \\
\hline S-11 & 0.03 & -0.03 & 0.02 & 0.03 & 0.00 & 0.04 & 0.03 & 0.05 & 0.02 & 0.00 & 0.00 & 0.02 & 0.20 & 3rd \\
\hline
\end{tabular}


The 12 criteria presented in Table 3 are measured according to the preferences of the decision makers, which are specific to small farms. The criteria and their measurement for the case of the chemical fertilizer were presented in Table 4 .

Table 4 also shows the characteristics of the selected criteria, as well as the measurement methods for choosing suppliers. Therefore, it is clear that the criteria should not be chosen based only on the literature, but also on the context and the characteristics of the decision makers involved in the process.

\section{Discussion}

The model was applied in a supplier selection process considering the three most relevant inputs for soybean cultivation (Fertilizers, Soybean Seed and Fungicide). The tables and calculations for the complete application are detailed in the supplementary document. The results were summarized in Table 12, illustrating the rankings found for suppliers in each approach considered (TCO \& MCDM and TCO + MCDM). These approaches encompass different concepts and cost management applications. The pure application of TCO determines that the best result for the decision maker is the option that has the lowest total cost, recommending that we should focus on minimizing costs.

Table 12. Summary of Rankings (TCO \& MCDM and TCO + MCDM).

\begin{tabular}{|c|c|c|c|c|c|c|c|c|c|}
\hline \multirow{2}{*}{ Alternatives } & \multicolumn{3}{|c|}{ Ranking Fertilizer } & \multicolumn{3}{|c|}{ Ranking Soybean Seed } & \multicolumn{3}{|c|}{ Ranking Fungicide } \\
\hline & TCO \& MCDM & TCO + MCDM & Avg & TCO \& MCDM & TCO + MCDM & Avg & TCO \& MCDM & TCO + MCDM & Avg \\
\hline S-1 & 1 st & 4th & 2nd & 1 st & 1 st & 1 st & 1 st & 1 st & 1 st \\
\hline S-2 & 6th & 7th & 6th & 5 th & $3 r d$ & 4th & 5 th & 6th & 6th \\
\hline S-3 & 5 th & 2nd & 4th & 2nd & 2nd & 2nd & 2nd & 2nd & 2nd \\
\hline S-4 & 8th & 8th & 8th & 10th & 9th & 9th & 10th & 10th & 10th \\
\hline S-5 & 9th & 9th & 9th & 7 th & 6th & 6th & 8th & 7 th & 8th \\
\hline S-6 & 7th & 6th & 7th & 6th & 8th & 7th & 3th & 5 th & 4th \\
\hline S-7 & 11th & 10th & 11th & 11th & 11th & 11th & 11th & 11th & 11th \\
\hline S-8 & 10th & 11th & 10th & 9th & 10th & 10th & 7th & 8th & 7th \\
\hline S-9 & 2nd & 1st & 1st & 8th & 7th & 8th & 9th & 9th & 9th \\
\hline S-10 & 4th & 5th & 5th & $3 \mathrm{rd}$ & 4th & 3rd & 6th & $3 \mathrm{rd}$ & 5 th \\
\hline S-11 & $3 \mathrm{rd}$ & $3 \mathrm{rd}$ & 3rd & 4th & 5 th & 5th & 4rd & 4th & $3 \mathrm{rd}$ \\
\hline
\end{tabular}

The approach using the multi-criteria, where the criteria weights are defined previously by the decision makers, provides results that combine the best alternatives defined by the decision makers and the TCO, which is not necessarily the less expensive alternative.

This new vision allows family farming to make a more assertive decision, according to their most relevant preferences. It should be noted that if the farmer wants to redefine the criteria weights, e.g., according to the needs of the activities in their farms, that can be carried out easily at any time, thus customizing the decision according to the context and the environment of each household farm and decision moment.

Table 12 shows the results of the rankings composed by the three inputs surveyed (Fertilizers, Soybean Seed and Fungicide) using the cost minimization (TCO \& MCDM) approach, and the weighted criteria and cost minimization (TCO + MCDM). In each column, the average composed by the two approaches is also presented, showing the ranking of the best suppliers taking into account all the stipulated criteria.

The column with the evaluation of the Fertilizer shows that the best solution considering TCO \& MCDM is "Supplier 1" (S-1) followed by "Supplier 9" (S-9). But, considering the weighted criteria specified by the decision makers, i.e., TCO + MCDM, "Supplier 9" (S-9) results the best option and "Supplier 3" (S-3) the second one. Considering the average of the two evaluations (TCO \& MCDM and TCO + MCDM) we have a similar situation, recognizing "Supplier 9" as the best option and "Supplier 1" as the second-best option. Therefore, it appears that for the acquisition of fertilizers, the best option, recognizing the minimization of TCO and the criteria which are relevant for the decision makers, is "Supplier 9" (S-9) and such option can provide substantial financial savings to the farmer.

Considering both TCO \& MCDM and TCO + MCDM approaches for the analysis of the three studied inputs (Fertilizers, Soybean Seed and Fungicide), "Supplier 1" (S-1) 
was the second-best option in the ranking for Fertilizer, and the best one for the other two inputs. The analysis of the other inputs can be found in the supplementary document.

The results reveal substantial opportunities for savings in the acquisition of the inputs of the soy culture, and corroborate the studies on TCO as Degraeve, et al. [38] which indicates that TCO helps purchasing managers to face competitive environments.

These savings reached approximately $13 \%$ for fertilizers, $7 \%$ for fungicide and $3 \%$ for soybean acquisition. The savings were calculated by comparing the best result obtained in the final ranking with the average of the other options that the decision-maker could find in the same scenario.

The results obtained show the relevance of the combined use of TCO and multi-criteria analysis to highlight a comprehensive set of relevant criteria, hidden costs, weights and decision maker's opinion. The demonstrated practical feasibility of the model is also an important aspect to be taken into consideration.

The proposed model and methodology are aligned with the claims of the literature. Indeed, TCO is presented as the most comprehensive and an efficient methodology to recognize all costs of the product highlighting the entire value chain $[23,47]$. The application of TCO in the agribusiness context has several examples which highlight its life cycle perspective, focus on the acquisition of inputs, and investment projects [31,44], respectively.

However, when we consider only the TCO perspective, focused on monetary costs, we might disregard important aspects related to the agribusiness activity, like quality, adaptations, failures, technical assistance, among others. Thus, the CMM includes the multi-criteria approach which has been widely used in the agribusiness and agricultural context, in general, and also to assist family farming $[51,55]$.

There is a very wider use of MCDA in the agribusiness context namely, for optimizing energy and the reuse of resources [55], optimization of planting [56], and for optimizing fuel consumption in heavy trucks [57]. However, in all these cases, costs are not considered comprehensively and significant indirect and hidden costs could be ignored resulting in a biased decision making asking for the use of TCO.

Thus, combining TCO and MCDA can be important to mitigate the limitations of the alternative use of each one to support decision making. Spite a few attempts, there is still a need for models which include both approaches. For example, Shabani et al. [43] combined Data Envelopment Analysis (DEA) and TCO, to reduce data inaccuracy and flaws of the traditional models which do not provide significant savings. However, this TCO-based DEA proved to be limited due to managers had difficulty to understand and accept the weighting schemes of DEA models, for the reason that traditional TCO requires a common set of weights. Moreover, the TCO-based DEA model is designed to use accurate data, while in practice we face often inaccurate data and conflicting aspects.

\section{Conclusions}

The difficulty in choosing the most appropriate purchasing alternatives in agribusiness becomes a limiting factor in the decision-making process and in the competitiveness of these businesses. Therefore, this study presents a model for cost management that integrates TCO and multi-criteria approaches named TCO-MCDM. This model can be applied in small farms in any region of the world, and its flexibility allows changes in weights and criteria at any time by the decision maker. The combination of TCO with MCDA contributes to increase the application of both approaches in practice and within more complex scenarios as recommended by Degraeve et al. [21,22].

The existing methodologies are not good enough for the definition of the best suppliers, and to provide an in-depth analysis of the costs related to each input and supplier. The proposed model provides an overview of the relevant costs, explicit and hidden, direct and indirect, as well as non-monetary criteria that traditionally cost models and MCDA do not consider. Because its simplicity and flexibility, it can be particularly useful to support decision making in family farming, contributing to the development of management practices in such context. 
Furthermore, this study improves also the understanding about the use of TCO and agricultural cost management, using the ranking procedure that allows the selection of inputs and suppliers, and also contributes to the scientific literature and the industry to disseminate the discussion and knowledge on the use of TCO in smallholder farmers, in addition to being a practical method to improve cost management.

The practical implications are related to the support that this model can give for decision making. Household farmers need to recognize all relevant costs, and to manage them in the most efficient way. There are also social implications which must be highlighted because more competitive farmers represent also improving of life quality in rural areas. The sustainability of these businesses contributes also positively to a higher the quality of agricultural products. From the financial point of view, the savings generated by better purchasing decisions may be used to support additional investments, increasing the financial sustainability in the long term, which consequently provides more income and improved quality of life and better products, as highlighted by Sharma [2].

The theoretical implications are related to the new approach proposed to manage costs, which considers TCO and multi-criteria analysis concomitantly. In family farming, the inclusion of MCDA provides a customization of the TCO adapting it to the reality of each rural farm. Furthermore, it highlights important factors for decision making such as those related to climate, exchange rate policies and future market outlook for the activities developed by farmers. All these aspects will be neglected if only costs were taken into account.

One of the limitations of this study is the fact that its application is restricted to the criteria defined by the smallholder farmers surveyed in a specific region and for a specific product. So, for its application in other environments, adaptations are needed in order to consider the characteristics and particularities of each situation.

As a future research opportunity, it may be highlighted the definition of criteria and their respective weights for agribusiness in a large number of different regions and contexts, in order to recognize the criteria and weights which characterize each region and also at the global level. Another opportunity that stands out is the application of the model to other agricultural businesses, with the aim of verifying the model's adherence to different contexts.

Supplementary Materials: The following are available online at https:/ / www.mdpi.com/2077-0 472/11/2/139/s1. Table S1. Evaluation Matrix for Soybean Seed; Table S2. Monetary Criteria for Soybean Seed; Table S3. Estimated Criteria for Soybean Seed; Table S4. Aggregated Ranking for Soybean Seed - TCO \& Multi-criteria; Table S5. Normalized (min/max) Matrix for Soybean Seed; Table S6. Normalized Weighted (V) Matrix for Soybean Seed; Table S7. Border Line Matrix (G); Table S8. Calculation of matrix Q and Ranking for Soybean Seed - TCO + MC; Table S9. Evaluation Matrix for Fungicide; Table S10. Monetary Criteria for Fungicide; Table S11. Estimated Criteria for Fungicide; Table S12. Aggregated Ranking for Fungicide - TCO \& Multi-criteria. Table S13. Normalized (min/max) Matrix for Fungicide; Table S14. Normalized Weighted (V) Matrix for Fungicide; Table S15. Border Line Matrix (G); Table S16. Calculation of matrix Q and Ranking for Fungicide - TCO + MC; Table S17. Normalized (min/max) Matrix for Chemical Fertilizer; Table S18. Normalized Weighted (V) Matrix for Chemical Fertilizer; Table S19. Border Line Matrix (G).

Author Contributions: M.L., P.A. and F.T. conceptualized the study; F.T., P.A. and M.L. assisted in the methodology; analysis was executed by M.L., P.A. and F.T.; validation was done by F.T. and P.A.; The original draft was written by M.L., P.A. and F.T. Review and editing were done by P.A., F.T. and M.L. All authors have read and agreed to the published version of the manuscript.

Funding: This study was financed in part by the Coordenação de Aperfeiçoamento de Pessoal de Nível Superior-Brasil (CAPES)_Finance Code 001.

Acknowledgments: Thanks to Federal University of Technology-Parana (UTFPR), Câmpus PG, Department of Production Engineering, Postgraduate Program in Production Engineering.

Conflicts of Interest: The authors declare no conflict of interest. 


\section{References}

1. Fisher, T. Cost Accounting Applied to Farming in Southwest Michigan. Ph.D. Thesis, Western Michigan University, Kalamazoo, MI, USA, 2012.

2. Sharma, R.S. Accounting for Agriculture. Int. J. Rec. Res. Rev. 2012, 2, 62-66.

3. Sharafat, A.A. Analyzing Farm Accounting Skills Related to Financial Performance of Dairy Industry: An Evidence from Jordan. J. Agric. Sci. 2016, 8, 174-180. [CrossRef]

4. FAO (Food and Agriculture Organization of the United Nations). Programs in Brazil: Food Security. Available online: http: / / www.fao.org/brasil/programas-e-projetos/programa/en/ (accessed on 26 May 2020).

5. European Union. Agriculture. Available online: https://europa.eu/european-union/topics/agriculture_en (accessed on 20 June 2020).

6. Daugbjerg, C. Policy feedback and paradigm shift in EU agricultural policy: The effects of the MacSharry reform on future reform. J. Eur. Public Policy 2003, 10, 421-437. [CrossRef]

7. Kilian, S.; Antón, J.; Salhofer, K.; Röder, N. Impacts of 2003 CAP reform on land rental prices and capitalization. Land Use Policy 2012, 29, 789-797. [CrossRef]

8. Tangermann, S. An Ex-Post Review of the 1992 MacSharry Reform. In The Reform of the Common Agricultural Policy; Ingersent, K.A., Rayner, A.J., Hine, R.C., Eds.; Palgrave Macmillan: London, UK, 1998.

9. Seldon, W.M.; Groenewald, J.A. Management Accounting in Agriculture. Agrekon 1966, 5, 19-29. [CrossRef]

10. Lizot, M.; Júnior, P.P.A.; De Lima, J.D.; Trojan, F. Method of cost management for agribusiness on small rural family properties. Agroalimentaria 2018, 24, 41-66.

11. Thesari, S.S.; Trojan, F.; Batistus, D. A decision model for municipal resources management. Manag. Decis. 2019, 57, 3015-3034. [CrossRef]

12. Bronson, K.; Knezevic, I.; Clement, C. The Canadian family farm, in literature and in practice. J. Rural Stud. 2019, 66, 104-111. [CrossRef]

13. Saint Ville, A.S.; Hickey, G.M.; Phillip, L.E. Institutional analysis of food and agriculture policy in the Caribbean: The case of Saint Lucia. J. Rural Stud. 2017, 51, 198-210. [CrossRef]

14. Nuthall, P.L. Determining the important management skill competencies the case of family farm business in New Zealand. Agric. Syst. 2005, 88, 429-450. [CrossRef]

15. Ederer, N. Evaluating capital and operating cost efficiency of offshore wind farms: A DEA approach. Renew. Sustain. Energy Rev. 2015, 42, 1034-1046. [CrossRef]

16. Rahman, S.; Barmon, B.K. Greening Modern Rice Farming Using Vermicompost and Its Impact on Productivity and Efficiency: An Empirical Analysis from Bangladesh. Agriculture 2019, 9, 239. [CrossRef]

17. Sussy, M.; Ola, H.; Maria, F.A.B.; Niklas, B.-O.; Cecilia, O.; Willis, O.-K.; Håkan, M.; Djurfeldt, G. Micro-Spatial Analysis of Maize Yield Gap Variability and Production Factors on Smallholder Farms. Agriculture 2019, 9, 219. [CrossRef]

18. Muniz Kubota, A.; Dal Belo Leite, J.G.; Watanabe, M.; Cavalett, O.; Leal, M.R.L.V.; Cortez, L. The Role of Small-Scale Biofuel Production in Brazil: Lessons for Developing Countries. Agriculture 2017, 7, 61. [CrossRef]

19. Lizot, M.; Andrade Júnior, P.P.; Trojan, F.; Magacho, C.S.; Thesari, S.S.; Goffi, A.S. Analysis of Evaluation Methods of Sustainable Supply Chain Management in Production Engineering Journals with High Impact. Sustainability 2020, 12, 270. [CrossRef]

20. Degraeve, Z.; Roodhooft, F.; Van Doveren, B. The use of total cost of ownership for strategic procurement: A company-wide management information system. J. Oper. Res. Soc. 2005, 56, 51-59. [CrossRef]

21. Degraeve, Z.; Roodhooft, F. Effectively Selecting Suppliers Using Total Cost of Ownership. J. Supply Chain Manag. 1999, 35, 5-10. [CrossRef]

22. Degraeve, Z.; Roodhooft, F. Improving the efficiency of the purchasing process using total cost of ownership information: The case of heating electrodes at Cockerill Sambre S.A. Eur. J. Oper. Res. 1999, 112, 42-53. [CrossRef]

23. Degraeve, Z.; Labro, E.; Roodhooft, F. An evaluation of vendor selection models from a total cost of ownership perspective. Eur. J. Oper. Res. 2000, 125, 34-58. [CrossRef]

24. Noll, P. Determining the real cost of powering a pump. World Pumps 2008, 496, 32-34. [CrossRef]

25. Sohn, S.Y.; Kim, Y.; Kim, B.T. Cost of ownership model for spare engines purchase for the Korean navy acquisition program. J. Oper. Res. Soc. 2009, 60, 1674-1682. [CrossRef]

26. Renquist, J.V.; Dickman, B.; Bradley, T.H. Economic comparison of fuel cell powered forklifts to battery powered forklifts. Int. J. Hydrog. Energy 2012, 37, 12054-12059. [CrossRef]

27. Ramadan, S.Z. Selection of Non-Repairable Series Systems' Components with Weibull-Life and Lognormal-Repair Distributions through Minimizing Expected Total Cost of Ownership Approach. Mod. Appl. Sci. 2013, 8, 104. [CrossRef]

28. Bjørkhaug, H.; Blekesaune, A. Gender and Work in Norwegian Family Farm Businesses. Sociol. Rural. 2008, 48, 152-165. [CrossRef]

29. Lizot, M.; Júnior, P.P.D.A.; Lima, J.D.D.; Magacho, C.S. Application of a model of management of costs for decision making in family agribusiness. Custos Agron. 2018, 14, 290-313.

30. Piedra-Muñoz, L.; Galdeano-Gómez, E.; Pérez-Mesa, J.C. Is Sustainability Compatible with Profitability? An Empirical Analysis on Family Farming Activity. Sustainability 2016, 8, 893. [CrossRef]

31. Lips, M. Length of operational life and its impact on life-cycle costs of a tractor in Switzerland. Agriculture 2017, 7, 68. [CrossRef] 
32. Govdya, V.V.; Khromova, K.N.; Vasilieva, N.K.; Sigidov, Y.I.; Polutina, T.N. Decomposition approach to formation of accounting and analytical system of cost management in agricultural enterprises. J. Exp. Biol. Agric. Sci. 2017, 5, 818-830. [CrossRef]

33. Hertsgaard, D.J.; Wilson, W.W.; Bruce Dahl, B. Costs and risks of testing and blending for essential amino acids in soybeans. Agribusiness 2018, 35, 1-16. [CrossRef]

34. Bojan, S.; Zorica, V.; Dragan, D.; Drago, C. Strategic cost management as instrument for improving competitiveness of agribusiness complex. Econ. Agric. 2014, 61, 1005-1021.

35. Kalogeras, N.; Pennings, J.M.E.; Doumpos, T.B.M. Which Cooperative Ownership Model Performs Better? A Financial-Decision Aid Approach. Agribusiness 2012, 29, 80-95. [CrossRef]

36. Heinemann, T.; Kaluza, A.; Thiede, S.; Ditterich, D.; Linzbach, J.; Herrmann, C. Life Cycle Evaluation of Factories: The Case of a Car Body Welding Line with Pneumatic Actuators. In IFIP Advances in Information and Communication Technology; Springer: Berlin/Heidelberg, Germany, 2014; pp. 546-554.

37. Caniato, F.; Ronchi, S.; Luzzini, D.; Brivio, O. Total cost of ownership along the supply chain: A model applied to the tinting industry. Prod. Plan. Control. 2015, 26, 427-437. [CrossRef]

38. Degraeve, Z.; Labro, E.; Roodhooft, F. Total cost of ownership purchasing of a service: The case of airline selection at Alcatel Bell. Eur. J. Oper. Res. 2004, 156, 23-40. [CrossRef]

39. Chawla, N.; Kumar, D. Desktop Virtualization-Desktop as a Service and Formulation of TCO with Return on Investment. Adv. Intell. Syst. Comput. 2018, 731, 599-608. [CrossRef]

40. Bacchetti, A.; Bonetti, S.; Perona, M.; Saccani, N. Investment and management decisions in aluminium melting: A total cost of ownership model and practical applications. Sustainability 2018, 10, 3342. [CrossRef]

41. Royer, J.S. Measuring the cost of capital in cooperative businesses. Agribusiness 2018, 35, 1-16. [CrossRef]

42. Lizot, M.; Júnior, P.P.A.; De Lima, J.D.; Trentin, M.G.; Setti, D. Economic analysis of black oats production for grazing and silage using the extended multi-index methodology. Custos Agron. 2017, 13, 141-155.

43. Shabani, A.; Visani, F.; Barbieri, P.; Dullaert, W.; Vigo, D. Reliable estimation of suppliers' total cost of ownership: An imprecise data envelopment analysis model with common weights. Omega 2019, 87, 57-70. [CrossRef]

44. Mochnacz, J.C.; Deimling, M.F.; Barichello, R.; Kliemann Neto, F.J.; Casarotto Filho, N. Application of Total Cost of Ownership (TCO) of a large agroindustry. Custos Agron. 2017, 13, 312-339.

45. Trybula, W. Cost of ownership-Projecting the future. Microelectr. Eng. 2006, 83, 614-618. [CrossRef]

46. Heinemann, T.; Schraml, P.; Thiede, S.; Eisele, C.; Herrmann, C.; Abele, E. Hierarchical evaluation of environmental impacts from manufacturing system and machine perspective. Proc. CIRP 2014, 15, 141-146. [CrossRef]

47. Scott, M.A.; Burke, G.; Szmerekovsky, J. Do as I Do and Not as I Say: Exploring Price-Oriented Maverick Buying During Supplier Selection. Decis. Sci. 2018, 49, 25-64. [CrossRef]

48. Degraeve, Z.; Labro, E.; Roodhooft, F. Constructing a Total Cost of Ownership supplier selection methodology based on Activity-Based Costing and mathematical programming. Acc. Bus. Res. 2005, 35, 3-21. [CrossRef]

49. Hofman-Caris, R.; Bertelkamp, C.; De Waal, L.; Van den Brand, T.; Hofman, J.; Van der Aa, R.; Van der Hoek, J.P. Rainwater harvesting for drinkingwater production: A sustainable and cost-effective solution in The Netherlands? Water 2019, 11, 511. [CrossRef]

50. Taefi, T.T.; Kreutzfeldt, J.; Held, T.; Fink, A. Supporting the adoption of electric vehicles in urban road freight transport-A multi-criteria analysis of policy measures in Germany. Transp. Res. Part A 2016, 91, 61-79. [CrossRef]

51. Tsoukiàs, A. From decision theory to decision aiding methodology. Eur. J. Oper. Res. 2008, 187, 138-161. [CrossRef]

52. Trojan, F.; Morais, D.C. Maintenance Management Decision Model for Reduction of Losses in Water Distribution Networks. Water Resour. Manag. 2015, 29, 3459-3479. [CrossRef]

53. Roy, B. Multi-Criteria Methodology for Decision Aiding; Kluwer Academic Publishers: Boston, MA, USA, 1996.

54. Castro Silva, A.C.G.; Fontes, C.H.O.; Barbosa, A.S. Multicriteria evaluation model for organizational performance management applied to the Polo Fruit Exporter of the São Francisco Valley. Comp. Electron. Agric. 2015, 117, 168-176. [CrossRef]

55. Komeleh, S.H.P.; Keyhani, A.; Rafiee, S.; Sefeedpary, P. Energy use and economic analysis of corn silage production under three cultivated area levels in Tehran province of Iran. Energy 2011, 36, 3335-3341. [CrossRef]

56. Kaim, A.; Cord, A.F.; Volk, M. A review of multi-criteria optimization techniques for agricultural land use allocation. Environ. Model. Softw. 2018, 105, 79-93. [CrossRef]

57. Fries, M.; Kruttschnitt, M.; Lienkamp, M. Operational Strategy of Hybrid Heavy-Duty Trucks by Utilizing a Genetic Algorithm to Optimize the Fuel Economy Multiobjective Criteria. IEEE Trans. Ind. Appl. 2018, 54, 3668-3675. [CrossRef]

58. Fagioli, F.F.; Rocchi, L.; Palotti, L.; Slowinski, R.; Boggia, A. From the farm to the agri-food system: A multiple criteria framework to evaluate extended multi-functional value. Ecol. Indic. 2017, 79, 91-102. [CrossRef]

59. Louwagie, G.; Northey, G.; Finn, J.A.; Purvis, G. Development of indicators for assessment of the environmental impact of livestock farming in Ireland using the Agri environmental Footprint Index. Ecol. Indic. 2012, 18, 149-162. [CrossRef]

60. García, J.L.; Alvarado, A.; Blanco, J.; Jiménez, E.; Maldonado, A.A.; Cortés, G. Multi-attribute evaluation and selection of sites for agricultural product warehouses based on an Analytic Hierarchy Process. Comp. Electron. Agric. 2014, 100, 60-69. [CrossRef]

61. Oliveira, M.W.; Agostinho, F.; Almeida, C.M.V.B.; Giannetti, B.F. Sustainable milk production: Application of the hierarchical analytical process towards a regional strategic planning. J. Environ. Account. Manag. 2016, 4, 385-398. [CrossRef] 
62. Hall, C.; McVittie, A.; Moran, D. What does the public want from agriculture and the countryside? A review of evidence and methods. J. Rural Stud. 2004, 20, 211-225. [CrossRef]

63. Fetanat, A.; Khorasaninejad, E. A novel hybrid MCDM approach for offshore wind farm site selection: A case study of Iran. Ocean Coast. Manag. 2015, 109, 17-28. [CrossRef]

64. IBGE (Brazilian Institute of Geography and Statistics). Brazilian Agricultural Census 2017. Available online: https://censos.ibge. gov.br/agro/2017/templates/censo_agro/resultadosagro/index.html (accessed on 10 December 2020).

65. FAO (Food and Agriculture Organization of the United Nations). FAO Participates in Panel on Brazilian Agriculture during International Conference on Fertilizers. Available online: http://www.fao.org/brasil/noticias/detail-events/en/c/1098805/ (accessed on 26 September 2020).

66. Pamucar, D.; Cirovic, G. The selection of transport and handling resources in logistics centers using Multi-Attributive Border Approximation area Comparison (MABAC). Exp. Syst. Appl. 2016, 42, 3016-3028. [CrossRef] 